\title{
Urgences
}

\section{Anonyme, A.}

\section{Élisabeth Haghebaert}

Numéro 15, octobre 1986

\section{Épigraphiques}

URI : https://id.erudit.org/iderudit/025301ar

DOI : https://doi.org/10.7202/025301ar

Aller au sommaire du numéro

\section{Éditeur(s)}

Urgences

\section{ISSN}

0226-9554 (imprimé)

1927-3924 (numérique)

Découvrir la revue

\section{Citer ce document}

Haghebaert, É. (1986). Anonyme, A. Urgences, (15), 34-34.

https://doi.org/10.7202/025301ar d'utilisation que vous pouvez consulter en ligne.

https://apropos.erudit.org/fr/usagers/politique-dutilisation/ 


\section{Élisabeth Haghebaert ANONYME, A.}

Le livre que je n'ai pas écrit ne parlait que de toi, dit Alissa.

Marguerite Duras: Détruire, dit-elle

Soir absolu. Le néon pleure. Écrit sur le toit: toute identité tue. En urgence donc, L. aussi. Une sorte de lavis un peu à la folie comme enjeu, ou pas du tout.

Obscurément, obstinément il pleut. La peur s'affole (série B) en lettres de feu, à signifier soudain. Un champ de pensées et de marguerites, très vivaces, les violettes et les blanches surtout. "Ne fais pas l'enfant, entends-tu", (mauvais sujet) toujours, la même chanson lointaine, petite. Jouons, dit-elle. Le rêve vieux usé de caresses: un désir de cloître, de mille ans peut-être. Comment dire "And so do I"? Tellement trop, une si tendre froideur d'ardoise et d'argile parfois déserte.

Je ne te dis pas, donc, l'heure ronde à consigner, les journées grandes ouvertes, comme embaumées, la transparence des roses.

Je sais, tu sais des mystères (conjuguez cent fois).

Mais, me diras-tu, ceux que tu ne connais pas? Comme portés par les vagues-chimères de leurs pays de mangues (la métisse danse et tangue - l'âme soul? - obsidienne et améthyste sous la jupe d'indienne). Vers d'amères amériques.

À parler comme on parle de palissandre et de Coromandel, j'en oublie Angkor, le camée, Compostelle et tes Méditerranées. Puisque toujours maintenant sous la pluie et la plume résurgente seule "l'urgence (interminable) des livres" et (illisible). 